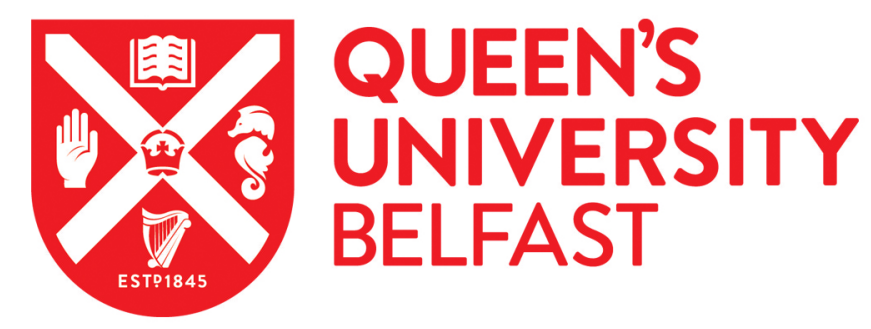

\title{
Designs from the deep: Marine organisms for bone tissue engineering
}

Clarke, S. A., Walsh, P., Maggs, C. A., \& Buchanan, F. (2011). Designs from the deep: Marine organisms for bone tissue engineering. Biotechnology Advances, 29(6), 610-617.

https://doi.org/10.1016/j.biotechadv.2011.04.003

\section{Published in:}

Biotechnology Advances

\section{Document Version:}

Peer reviewed version

\section{Queen's University Belfast - Research Portal:}

Link to publication record in Queen's University Belfast Research Portal

\section{Publisher rights}

Copyright 2011 Elsevier.

This manuscript is distributed under a Creative Commons Attribution-NonCommercial-NoDerivs License

(https://creativecommons.org/licenses/by-nc-nd/4.0/), which permits distribution and reproduction for non-commercial purposes, provided the author and source are cited.

\section{General rights}

Copyright for the publications made accessible via the Queen's University Belfast Research Portal is retained by the author(s) and / or other copyright owners and it is a condition of accessing these publications that users recognise and abide by the legal requirements associated with these rights.

Take down policy

The Research Portal is Queen's institutional repository that provides access to Queen's research output. Every effort has been made to ensure that content in the Research Portal does not infringe any person's rights, or applicable UK laws. If you discover content in the Research Portal that you believe breaches copyright or violates any law, please contact openaccess@qub.ac.uk. 
Designs from the Deep: Marine Organisms for Bone Tissue Engineering

S.A. Clarke*1, P. Walsh¹, C.A. Maggs ${ }^{1}$, F. Buchanan ${ }^{2}$

${ }^{1}$ School of Biological Sciences, Queen's University Belfast, Medical Biology Centre, Belfast, UK ${ }^{2}$ School of Mechanical and Aerospace Engineering, Queen's University Belfast, Ashby Building, Belfast, UK *corresponding author 


\section{Abstract}

Current strategies for bone repair have accepted limitations and the search for synthetic graft materials or for scaffolds that will support ex vivo bone tissue engineering continues. Biomimetic strategies have led to the investigation of naturally occurring porous structures as templates for bone growth. The marine environment is rich in mineralizing organisms with porous structures, some of which are currently being used as bone graft materials and others that are in early stages of development. This review describes the current evidence available for these organisms, considers the relative promise of each and suggests potential future directions. 
Introduction

Bone grafting is used routinely in orthopaedic and dental surgery for procedures such as spinal fusion, foot and ankle arthrodesis, impaction grafting during revision surgery, stimulation of healing in fracture non-unions and void filling following tumour resection. In the reconstruction of bony deficits, autologous or allogenic bone has proven most effective, however, their use is not without problems. Autograft harvest has associated significant donor site morbidity and restrictions on the amount of graft material available, particularly if the patient is elderly and bone stock is deteriorating. Allograft also has limited stocks(Galea et al., 1998), a clinical failure rate of 20-30\% and concerns about immunogenicity (Louisia et al., 1999; Summers and Eisenstein, 1989; Wooley et al., 1996). Furthermore, it is likely that with increasing concerns over transmissible spongiform encephalopathies the use of allograft material will be more tightly regulated and restricted in the near future.

Currently, the majority of clinically available and experimental synthetic bone graft materials are calcium phosphate (CaP) ceramics. Approximately $60 \%$ of bone consists of the mineral phase hydroxyapatite (HA), therefore structures containing HA or related CaPs, (e.g. beta-tricalcium phosphate) are natural choices as bone substitutes and scaffolds for bone tissue engineering (Rezwan et al., 2006). Although the biological performance of CaPs is well proven and they possess excellent biocompatibility and osteoconductive properties, clinical results continue to be inferior to those seen with autograft or allograft. Therefore, development of new or modified synthetic bone substitutes continues apace (Bohner et al., 2005).

It is the general consensus among the scientific and orthopaedic communities that the ideal material for bone tissue engineering should provide initial mechanical strength and support, with gradual resorption and replacement by newly synthesized host tissue. When calcium phosphates were first investigated as bone graft substitutes, dense material in granule or particulate form was often implanted but as these ceramics are only partially resorbable, replacement by new bone is incomplete 
and the biomaterial remains in situ for many years. Development of advanced production methods and a desire to mimic more closely the natural structure of bone led to the production of porous materials that are more easily infiltrated by host tissue (Shors, 1999). Porous materials allow improved interdigitation with host bone, improved vascularization and fluid exchange. Several studies have suggested that the optimum pore size for neovascularization and bone ingrowth is between 200 $\mu \mathrm{m}$ and $500 \mu \mathrm{m}$ (Green et al., 2002; Wiesmann et al., 2004) and that good connectivity of the pores throughout the scaffold is essential (Shors, 1999). This advancement in design, coupled with the principles of biomimetics and an interest in ex vivo tissue engineering of bone has led to a search for naturally occurring scaffolds that could be used for the purpose of bone regeneration.

The marine environment is a rich source of organisms with unique bone-like structures. Coral has been the most widely used - in the early 1970s, White (White, 1997) suggested that a variety of corals and echinoids with unique 3-D structures, described by Weber in the 1960s, may have a potential application for orthopaedics - but in the last five years, calcified materials from a diverse range of marine invertebrates have been investigated for use in bone tissue engineering. This review will compare the published results for each of these sources and will consider the relative promise of each organism, taking into consideration concerns of sustainability and conservation.

\section{Coral}

Corals belong to the phylum Cnidaria, and most belong to class Anthozoa (Castro and Huber, 2008). Many soft corals have an internal structure that features calcium carbonate spicules but it is the hard, or stony, corals which are used for bone tissue engineering (Shors, 1999). Stony corals secrete an external calcium carbonate skeleton, mainly in the form of aragonite with some calcite (AbramovitchGottlib et al., 2006; Allemand et al., 1998). This skeleton, combined with an open, highly interconnected porous structure, make them of interest as scaffolds for bone tissue engineering. Most of the corals that have been investigated thus far for use as scaffolds for bone growth have pore sizes 
between $100 \mu \mathrm{m}$ and $500 \mu \mathrm{m}$ diameter with a high degree of connectivity (Abramovitch-Gottlib et al., 2006; Geiger et al., 2007; Green et al., 2002; Mygind et al., 2007; Shors, 1999; Wiesmann et al., 2004).

Clinically, coral scaffolds or coral-derivatives have been used for spinal fusion (Coughlin et al., 2006; Griesshaber et al., 2007; Im et al., 2005), in maxillofacial surgery (Chen et al., 2008b; Green et al., 2003; Laza et al., 2007; Oliveira et al., 2007), dental surgery (Lahaye and Robic, 2007; Martina et al., 2005) and for other orthopaedic applications (Bachle et al., 2006; Coughlin et al., 2006; Hou et al., 2007; Kujala et al., 2002), either alone (Chen et al., 2008b; Coughlin et al., 2006; Green et al., 2003; Hou et al., 2007; Im et al., 2005; Lahaye and Robic, 2007; Laza et al., 2007; Oliveira et al., 2007), or as part of a composite material (Bachle et al., 2006; Coughlin et al., 2006; Griesshaber et al., 2007; Martina et al., 2005) with reported success and low complication rates, an exception being a clinical study of scaphoid non-unions in which autograft was supplemented with coral/BMP implants and poor results were blamed on poor vascularity (Kujala et al., 2002).

Experimentally, in vitro testing of corals directly as scaffolds to support osteogenic cell attachment, growth and differentiation has shown that primary human bone-derived osteoblasts (Doherty et al., 1994) and a mouse mesenchymal cell line (CRL-12424) attached and spread on the coral (Porites lutea) surface displaying a fibroblast-like morphology (Gravel et al., 2006). A similar study using the same cell line demonstrated cell proliferation on the surface of two corals (Millepora dichotoma and Porites lutea) with temporal expression of alkaline phosphatase and osteocalcin (measures of osteogenic differentiation) and evidence of mineralization (Abramovitch-Gottlib et al., 2006). Cui et al showed similar results in vitro with adipose-derived stem cells from dogs (Cui et al., 2007). In vivo, an early study reported successful healing of cortical and cancellous, non-critical and critical sized bone defects in dogs using four different corals; Porites, Goniopora, Favites or Lobophyllia (Guillemin et al., 1987) and Gao et al reported superior healing of a segmental tibial defect in sheep with coral compared to tricalcium phosphate (Ohgushi, 1997). However, these early successes have been 
followed by reports of the inability of coral alone to support effective bone healing (Galea et al., 1998; Laza et al., 2007; Mygind et al., 2007).

In common with other synthetic CaP bone substitutes, corals have been shown to have limited osteoinductive capacity and it is only with the addition of osteogenic cells onto the coral construct that ectopic bone formation is demonstrated (Chen et al., 2007; Ohgushi, 1997; Zhang et al., 2007b). Therefore many studies investigating the ability of coral to support bone healing in vivo have included the use of osteogenic growth factors or cells to enhance the osteoinductive capability of the construct. In a rabbit model of spinal fusion, a Biocoral/collagen scaffold with bovine-derived bone protein extract resulted in solid fusions compared to scaffold alone (Mygind et al., 2007): a bone morphogenetic protein (BMP) loaded coral scaffold also improved healing in a canine long bone defect (Harris and Cooper, 2004) and rabbit calvarial defect (Hou et al., 2007). Cui et al showed that enhanced healing occurred at 12 and 24 weeks for a cranial defect in dogs when adipose-derived autologous stem cells were added to the coral scaffold (Cui et al., 2007). In the group which received coral alone, there was minimal new bone formation and much of the coral had been resorbed by 24 weeks leaving an empty defect. Similar results were reported by Geiger et al in a rabbit radial defect (Geiger et al., 2007) and Louisia et al in a rabbit ulnar defect (Louisia et al., 1999) with coral alone showing minimal bone formation but healing enhanced by the addition of autologous bone marrow stromal cells. Both studies used Biocoral ${ }^{\circledR}$ which is a commercially available bone substitute material from purified coral (Porites sp.) exoskeletons (Table 1). The coral is chemically treated to remove amino acids, artefacts and foreign bodies, but there is no alteration to its chemical or crystalline structure (Cirutteau, 1979; White, 1997). Geiger et al (Geiger et al., 2007) and Louisia et al (Louisia et al., 1999) both also reported substantial resorption of the coral scaffold after several weeks - a finding that is supported by others (Bensaid et al., 2005; Guillemin et al., 1987; Ohgushi, 1997).

Based on these results, Louisia et al suggested that resorption of the coral scaffold could be one of the main benefits of its use as a bone tissue construct compared to other, more frequently used ceramics 
such as hydroxyapatite. One of the perceived disadvantages of using CaP ceramics clinically is the relatively slow resorption rate. Although some formulations, such as those with a greater proportion of $\beta$ tri-calcium phosphate, have a faster resorption rate, in general CaP resorption is slow and hydroxyapatite (the most commonly used synthetic bone graft material) can remain at the implantation site for several years (von Doernberg et al., 2006). One of the goals of bone tissue engineering research is to produce a scaffold that is removed at the same rate as new bone is laid down so that it supports, but does not impede, bone repair. Some synthetic bone substitutes such as calcium sulphate (Cook and Cook, 2009) are resorbed too quickly to support bone cell attachment and bone growth, so could the calcium carbonate skeleton of coral be the optimum material?

Although these early results of Louisia et al and others showed promise, as with many in vivo studies, they lacked meaningful control groups and favoured inclusion of an empty defect group over the more useful positive control. This was rectified in the group's subsequent studies which compared the cellseeded coral scaffolds to clinically relevant control groups such as coral mixed with fresh bone marrow (Petite et al., 2000) and defects filled with autograft (Viateau et al., 2007). Further study by this group, and others, showed that resorption rate of the coral scaffold is very finely balanced. Tuominen et al reported that adding BMP to the coral scaffold accelerated the rate of resorption (Tuominen et al., 2000). Furthermore, the addition of fresh bone marrow (Petite et al., 2000) or vascular endothelial growth factor (VEGF)-producing bone marrow stromal cells (Geiger et al., 2007) caused the scaffold to resorb too quickly resulting in bone formation rates lower than those seen with cell-seeded constructs. This is in direct contrast to the enhanced bone formation rates found when bone marrow or VEGF was added to a CaP scaffold (Clarke, 2007) and suggests that, with further development, it may indeed be possible to engineer materials with resorption rates tailored to a specific clinical application. Certainly, coral scaffolds seeded with osteogenic cells showed promise in these studies and may provide a more appropriate scaffold for cell-based therapies than CaP ceramics. When compared with autograft control, cell-seeded coral scaffolds showed similar bone formation rates, however, radiographically, complete bridging of the defect was superior in the autograft group 
(Viateau et al., 2007) and this may affect clinical outcomes. Furthermore, Bensaid et al, who also investigated the ability of MSC-loaded coral scaffolds to repair large bone defects in sheep, found that the coral scaffold resorbed too quickly to support bone formation in most instances, even with the cell-loaded constructs (Bensaid et al., 2005). Differences in experimental protocols may account for the discrepancy between these and the results of Petite's group (Louisia et al., 1999; Petite et al., 2000; Viateau et al., 2007) as Bensaid et al loaded their scaffold with 640 times more cells and so may have provided too much stimulus for resorption similar to that seen with whole bone marrow and growth factors.

An alternative to using coral directly as a scaffold to support bone growth was first investigated by White and Shors in 1972, when they successfully fabricated replicas of the coral structure from $\mathrm{TiO}_{2}$, $\mathrm{Al}_{2} \mathrm{O}_{3}$ and $\mathrm{HA}$ into bone-like plugs (White et al., 1972). In 1974, Roy and Linnehan took a simpler biomimetic approach, employing the direct conversion of coral calcium carbonate skeletons into HA (termed coralline HA) (Roy and Linnehan, 1974). The years of scientific research that followed have resulted in the development of coral-based commercially available products for bone repair (Table 1). These products (Pro-Osteon ${ }^{\mathrm{TM}}$ 200R, Pro-Osteon ${ }^{\mathrm{TM}}$ 500R) are only partially converted and so have an outer HA layer (2-5 $\mu \mathrm{m}$ thick) with an inner aragonite core (White and Shors, 1986; White and Shors, 1989). This may provide a solution to the problem of expeditious resorption of the coral scaffold when too much of a stimulus is given: the outer HA layer may slow down the resorption rate, yet the more soluble inner core will counter the slow remodeling typical of bone substitutes produced from unadulterated HA. One concern with HA coated corals in vivo is that, when the HA coating is breached, fast resorption of the core will result in a massive increase in localized extracellular calcium and this, as much as the lack of a physical scaffold, may impede bone growth. There is some evidence that, although small amounts of calcium will enhance bone cell proliferation and differentiation, too much may inhibit both osteoblast (Maeno et al., 2005) and osteoclast (Hall, 1994; Yamada et al., 1997; Zaidi et al., 1989) function. 
In practice, however, the coralline HA scaffold has shown very little ability to resorb. Bensaid et al reported that there was little evidence of resorption of a Pro-Osteon ${ }^{\mathrm{TM}}$ Pro-Osteon ${ }^{\mathrm{TM}}$ 200R scaffold in a sheep long bone defect even after 16 weeks when the majority of an unconverted coral scaffold had been resorbed (Bensaid et al., 2005) and in a clinical trial of Pro-Osteon ${ }^{\mathrm{TM}} 500 \mathrm{R}$ as an alternative to autograft for hind foot arthrodesis in ten patients, the Pro-Osteon ${ }^{\mathrm{TM}}$ was still visible on $\mathrm{x}$-ray more than six years after surgery (Coughlin et al., 2006). Furthermore, others have shown that ProOsteon $^{\mathrm{TM}}$ 500R did not support ectopic bone formation even when seeded with osteogenic cells, unlike conventional CaP scaffolds (Harris and Cooper, 2004). A review by Shors suggests resorption rates for coralline HA in a canine model of $2-5 \%$ per year in cancellous sites and 25\% per year in cortical defects compared to rates of $65 \%$ in 2 weeks for the natural coral graft (Shors, 1999). It is thought that the inability of coralline HA to be resorbed in vivo is due to the highly crystalline nature of the HA coating, which is less soluble (Harris and Cooper, 2004). Therefore, although Pro-Osteon ${ }^{\mathrm{TM}}$ can conduct bone formation and has been shown to be an effective bone graft for several applications (Coughlin et al., 2006), it should be considered a permanent or slow-resorbing biomaterial and does not provide the half-way house of resorption rate between coral and CaP that might have been expected.

Current commercially available materials use high pressure-temperature synthesis to achieve the HA coating on the coral surface. Several other fabrication techniques, such as replication and microwave synthesis, have also been investigated (table 2). Recently, research into the use of corals as bone substitutes has focused on the hydrothermal conversion of alternative species such as a coral from the Gulf of Mannar, off the coast of India (Sivakumar et al., 1996); modifications to the conversion process such as the addition of a second coating step to improve the mechanical properties (Hu et al., 2001); or the use of alternative, more sustainable species (Abramovitch-Gottlib et al., 2006). The slow growth rate of corals makes sustainability a major concern for their continued use in bone tissue engineering. To meet the market demand, BiometInterpore (manufacturers of Pro-Osteon ${ }^{\mathrm{TM}}$ ) requires 2-4 tons of coral per year from the Pacific and Indian Oceans (Ritter, 1997). 
Since 1990, all species of stony coral have been listed under the Convention on International Trade in Endangered Species (CITES) treaty Appendix II (vulnerable to exploitation but not yet at risk of extinction) (Harriott, 2003). Compared to the damage inflicted on coral reefs by environmental stresses such as pollution and storm damage and by intensive fishing methods such as dynamite fishing, commercial coral harvesting probably has a relatively low impact. However, extensive farming of accessible reefs may lead to localized habitat destruction and overfishing of one or two target species may mean the reef overall is maintained but individual species are lost (Harriott, 2003).

Options for farming corals include strict management and control over the reef such as occurs in Australia, on the Great Barrier Reef in particular, or culturing corals in aquaria - one of the benefits cited by Abramovitch-Gottlib et al for using the hydrocoral Millepora dichotoma in their recent studies (Abramovitch-Gottlib et al., 2006) For some of the branching corals, small pieces can be harvested grown in aquaria to commercially suited sizes and sold, by which time stocks in the wild have also replenished. In general, there is a location- and species-specific answer to the question of whether coral can be harvested sustainably (Harriott, 2003). Some algal species also have a calcareous skeleton and with a growth rate of $2.6 \mathrm{~cm} /$ year, compared to an average of $1 \mathrm{~cm} /$ year for coral species (Harriott, 2003), they may provide a more sustainable alternative for bone tissue engineering (FelicioFernandes and Laranjeira, 2000).

\footnotetext{
Algae

There are three types of algae - red, brown and green, but it is species of red algae (phylum Rhodophyta), specifically a group of coralline algae, that have been used in bone tissue engineering. Coralline algae deposit calcium carbonate, in the form of calcite, in their cell wall and, in warm marine environments, have been shown to participate in reef building (Castro and Huber, 2008).
} 
Unlike the corals, coralline algae have not been used in the native form as a scaffold or bone substitute but have instead been converted to calcium phosphate using similar hydrothermal conversion methods as those used to synthesise Pro-Osteon ${ }^{\mathrm{TM}}$. This was first described using Corallina officinalis by Roy and Linnehan in 1974 (Roy and Linnehan, 1974) and later developed by Kasperk et al in the late 1980's (Kasperk et al., 1988). This latter research group has published an extensive body of work in the intervening decades. Despite the fact that the pores of this algae, although interconnected, are approximately 5-10 $\mu \mathrm{m}$ (figure 1) (Schopper et al., 2005; Walsh et al., 2008) and therefore considered suboptimal for tissue and vascular ingrowth (Felicio-Fernandes and Laranjeira, 2000), the coralline HA scaffold has been shown to support the attachment, proliferation and differentiation of both primary human bone-derived cells (Turhani et al., 2005a; Turhani et al., 2005c) and mesenchymal cambial-layer precursor cells (Turhani et al., 2005b). Furthermore, a commercially available CaP product derived from C. officinalis, AlgiPore (also marketed as C GRAFT, Algisorb and AlgOss) has a relatively long history of clinical use in maxilla sinus grafting: in 2005, Ewers reported the long term follow-up (up to 13 years) of over 200 sinus grafts with a $95.6 \%$ survival rate (Ewers, 2005).

As the algal-derived HA is produced by similar methods to coral-derived HA, there are similar concerns about the resorptive capacity of this graft. Ewers reported that there was only a $14 \%$ volume loss of the material after six months in his clinical study of AlgiPore and some graft material was still visible even after six years (Ewers, 2005). In an attempt to increase the resorption rate, biphasic CaP materials were produced from the algal template, with various ratios of HA to $\beta$ tricalcium phosphate (TCP) (Spassova et al., 2007). In a cortico-cancellous defect model in sheep, biphasic materials with HA:TCP ratios of 50:50 and 30:70 did show a statistically significant decrease in residual graft volume and an increase in bone volume after 6 months compared to 100\% HA but there was no further reduction in the material volume of any of the materials at 12 months and considerable amounts of even the 30:70 graft remained (Schopper et al., 2005). 
Another strategy for counteracting the lack of resorption of the coralline HA grafts may be to use alternative production techniques. In 2008, Walsh et al described production of an HA bone graft from C. officinalis using low temperature hydrothermal synthesis that resulted in semi-amorphous HA rather than the highly crystalline material produced by previous methods (Walsh et al., 2008). In theory, this material should be more resorbable in vivo but we must await further publications confirming both this and biocompatibility of the graft.

\section{Cuttlefish}

Although there are tens of thousands of marine unicellular and multicellular organisms that produce some form of mineral, species from only four further invertebrate phyla have been investigated for bone tissue engineering, namely Mollusca, Arthropoda, Echinodermata and Porifera (Table 3). Of these, cuttlefish (Phylum Mollusca, Class Cephalopoda) have been the most extensively studied. Four groups have described the conversion of a single species of cuttlefish, Sepia officinalis, from the natural aragonite calcium carbonate mineral to carbonated HA (Ivankovic et al., 2009; Kasioptas et al., 2010; Lee et al., 2007; Rocha et al., 2005b). The resulting structure (figure 1) has a high percentage porosity (80\%-94\%) and with pore sizes in the range of 200-600 $\mu \mathrm{m}$ (Kim et al., 2008) may provide a more optimized scaffold for bone tissue ingrowth and revascularization than either coral or coralline algae.

To date, however, this remains untested as the current in vitro and in vivo testing published is of a very limited nature (Rocha et al., 2006; Rocha et al., 2005a) or has only been presented in short paper form (Kim et al., 2008). In vitro studies were short-term (up to 72 hours) and were concerned with initial biocompatibility of the material and therefore tested proliferation and alkaline phosphatase expression of primary osteoblasts in the presence of, and not directly attached to, powdered converted cuttlefish bone (Rocha et al., 2005a) or whole constructs (Rocha et al., 2006). No cytotoxic results were reported. In vivo, no inflammatory response to converted cuttlefish (Sepia esculenta) implanted in a rabbit femoral condylar defect was reported but no quantification of healing or bone formation 
was performed (Kim et al., 2008). One study has suggested that cuttlefish "bone" can directly support bone formation, without requiring hydrothermal conversion to HA, and may be suitable as a potential xenograft for bone healing as Sepia officinalis was tested in a bone defect model against currently available synthetic graft and xenograft materials (Okumus and Yildirim, 2005). Again, this requires further investigation and there are some concerns about the mechanical strength of the raw material as it is malleable and easily shaped, but in general this represents a potential new direction for bone tissue engineering. Carbonated HA is closer to the chemistry of natural human bone than stoichiometrically pure HA (Bigi et al., 1997)and has been shown experimentally to have enhanced biocompatibility (Ellies et al., 1988; Landi et al., 2003). The methods described to convert cuttlefish aragonite seemed to result in substitution of carbonate ions in a similar location within the HA structure to bone (Ivankovic et al., 2009; Kasioptas et al., 2010) and with cuttlefish in relative abundance in tropical and temperate seas (Okumus and Yildirim, 2005), sustainability may not be a concern making this resource of significant interest.

\section{Arthropoda and Echinodermata}

Ion substitution of HA has been a strategy employed extensively to improve the biological performance of calcium phosphate and two groups of the phylum Echinodermata, sea stars (class Asteroidea) and sea urchins (class Echinoidea), have ossicles and spines made of Mg-rich calcite. Ossicles from the seastar, Pisaster giganteus, have been shown to support human bone-derived osteoblast and human bone marrow stromal cell attachment directly to the porous structure (Martina et al., 2005) whereas spines from two species of sea urchins, Heterocentrotus trigonarius and Heterocentrotus mammillatus, were converted to CaP before use (Vecchio et al., 2007b) The biogenic Mg-rich calcite spines resulted in Mg-substituted tricalcium phosphate (TCP) rather than HA when converted. The structure had pores in the range of 20-50 $\mu \mathrm{m}$ with trabecular struts of $100 \mu \mathrm{m}$ and showed no inflammatory reaction and bony apposition when implanted in a rat femoral defect model (Vecchio et al., 2007b). These are very early results but using an ion-rich biogenic source of calcite or aragonite as a starting material may provide scaffolds with optimal biocompatibility using simple 
processing methodology, avoiding the need for complex reactions to obtain ion-substitution, such as those employed by Kannan et al to obtain fluorine ion substitution during conversion of cuttlefish bones (Kannan et al., 2007). However, most sea urchin spines are too small to be of practical use and with only two species currently identified as having spines large enough to provide useful scaffolds, sustainability must be a concern.

Conversely, seashells and the exoskeletons of many arthropods such as crab and lobster are large enough to provide structures for any application. In a study examining the conversion of Giant clam (Tridacna gigas) and conch (Strombus gigas) shells, Vecchio et al showed that even when partially converted to HA (i.e. the structure has an outer $\mathrm{HA}$ shell and inner $\mathrm{CaCO}_{3}$ core) the mechanical strengths were similar to that of human bone perhaps allowing this particular material to be used for load bearing applications (Vecchio et al., 2007a). A further advantage of this biogenic source is that the large pieces can be machined into any shape. The authors give screws as an example and potential application, however, the material is non-porous and even though initial in vivo studies demonstrated bone apposition in a rat femoral defect model, with no evidence of material resorption at 6 wks, long term removal of the material may be a problem.

Crustacean exoskeletons may provide a solution to this. Studies of lobster (Homarus americanus) (Raabe et al., 2005) and the sheep crab (Loxorhynchus grandis) (Chen et al., 2008b) showed that their mineralized chitin exoskeletons have excellent material properties, high degrees of strength due to the 'twisted plywood' structure and, in the case of the lobster, a porous honeycomb structure at the micron level. Use of these exoskeletons as graft materials has not been investigated, however, as $\mathrm{CaCO}_{3}$ has been shown to support bone growth in some of the studies outline previously, and chitin has been extensively studied as part of composite materials for biomedical devices (Khoushab and Yamabhai), there is no reason to suppose that crustacean exoskeletons will not support bone formation. Even if, however, they are not directly suitable as xenografts, studying their complex 
architecture and morphology may provide inspiration for synthetic nanocomposite material design (Chen et al., 2008a; Giraud-Guille et al., 2004).

\section{Porifera}

The final group of marine invertebrates investigated for the ability to support bone formation is the sponges (Porifera). Some sponges have a $\mathrm{CaCO}_{3}$ skeleton but the majority has a protein skeleton made from spongin with or without additional support from siliceous spicules (Castro and Huber, 2008). Spongin is comparable to vertebrate collagen and as such has been extracted for use as a functional additive to composite biomaterials. In one study, sponge (Chondrosia reniformis)- derived collagen was used in conjunction with silica templating to produce hydrogels which supported attachment and growth of an osteoblast-like cell line (Heinemann et al., 2007). Sponges themselves have also been examined as suitable scaffolds for bone tissue engineering. In two separate studies, six different "unidentified" sponges were found to support human BMSC (Green et al., 2003) and mouse calvarialderived primary osteoblasts (Zheng et al., 2007) attachment and differentiation demonstrated by alkaline phosphatase expression or activity. Green et al subsequently identified their sponge as Spongia officinalis, a Mediterranean bath sponge, and showed that it also supported ectopic bone formation when implanted in a subcutaneous pouch athymic mouse model (Green, 2008).

More recently, three sponges from the genus Spongia (S. officinalis, S. zimocca, and S. agaricina) were used as precursors, or templates, to produce porous HA scaffolds by a replication technique (Cunningham et al., 2010). Of the three sponges examined, Spongia agaricina produced the most promising replicated scaffold for bone tissue engineering as it had approximately $60 \%$ porosity with pore sizes in the range of 100-500 $\mu \mathrm{m}$ and 99.9\% interconnectivity (figure 1). Therefore sponges could prove to be useful on a number of fronts, either as a source of collagen for hydrogel production or as an additive to synthetic CaP or polymer scaffolds, as templates for producing biomimetic ceramic scaffolds or directly as osteoconductive grafts. There is one serious drawback to the continued use of sponges as biomaterials, however, and that is one of sustainability. Sponges have been used for 
centuries for numerous applications, most notably in the cosmetics industry. Those species that produce bioactive compounds are also increasingly being sought for use in biomedical fields. Demand now far outweighs supply of some species, particularly Mediterranean bath sponges, and has resulted in their inclusion on endangered and protected species lists (Baldacconi et al., 2010; Corriero et al., 2004). Currently, methods of farming these sponges (Corriero et al., 2004; Muller et al., 1999), or of transplanting them back into protected areas from which they have become extinct (Baldacconi et al., 2010) are being investigated. Unless these studies prove successful or alternative species of sponge which are not endangered are found, these animals may not prove to be suitable for orthopaedic applications in the long term.

\section{Future Directions}

The philosophy of biomimetics has provided a new direction for biomaterial design. Early forays in this area began with researchers trying to recreate the natural structure of bone on a microscale by mimicking the trabecular porous structure and collagen fibre/mineral composite chemistry and has now progressed to mimicking cortical bone on a macroscale, producing materials with a dense outer layer and inner cavity (Zhang et al., 2007a). Reproducing the porosity of human bone has provided some degree of success but may be limited by production methods, for example the use of synthetic performs, which often result in partially closed porous structures with limited connectivity or low tortuosity (the ease of a path through the porous structure). This has driven a search for naturally occurring porous structures which can either be used directly as scaffolds or to provide templates for producing novel biomaterials.

We have seen above that the seas and oceans are a rich source of mineralized organisms that may be of benefit for this purpose. Research into these sources is in its relative infancy and there remains much work to be done with those already identified and many hundreds more that are yet untapped. As we progress towards 'smart' biomaterials that are application specific and have tailored resorption and osteoconductive profiles, it may be that we can utilize many of these resources - using the more 
resorbable $\mathrm{CaCO}_{3}$ structures directly for short term support, using sources rich in $\mathrm{Mg}$, $\mathrm{Si}$ or other ions to produce ion-substituted $\mathrm{CaP}$ with intermediate resorption profiles, or converting porous $\mathrm{CaCO}_{3}$ skeletons with optimal pore size and connectivity to provide long term scaffolds for ex vivo bone tissue engineering. The opportunities in the marine environment are almost limitless - in fact, as long as we ensure from the beginning that the resources we use are truly sustainable, the seabed is the limit.

\section{Acknowledgements}

The authors wish to thank Margaret Millar and Katherine Fee for contributions and acknowledge financial support from the Marine Biodiscovery Beaufort Research Award which is carried out under the Sea Change Strategy and the Strategy for Science Technology and Innovation (2006-2013), with the support of the Marine Institute, Ireland.

\section{References}

1 Abramovitch-Gottlib L, Geresh S, Vago R Biofabricated Marine Hydrozoan: A Bioactive Crystalline Material Promoting Ossification of Mesenchymal Stem Cells. Tissue Engineering 2006;12:729-739.

2 Allemand D, Tambutte E, Girard JP, Jaubert J Organic Matrix Synthesis in the Scleractinian Coral Stylophora Pistillata: Role in Biomineralization and Potential Target of the Organotin Tributyltin. Journal of Experimental Biology 1998;201:2001-2009.

3 Bachle M, Hubner U, Kohal RJ, Han JS, Wiedmann-Al-Ahmad M Structure and in Vitro Cytocompatibility of the Gastropod Shell of Helix Pomatia. Tissue \& Cell 2006;38:337-344.

4 Baldacconi R, Cardone F, Longo C, Mercurio M, Marzano CN, Gaino E, Corriero G Transplantation of Spongia Officinalis L. (Porifera, Demospongiae): A Technical Approach for Restocking This Endangered Species. Marine Ecology-An Evolutionary Perspective 2010;31:309317.

5 Bensaid W, Oudina K, Viateau V, Potier E, Bousson V, Blanchat C, Sedel L, Guillemin G, Petite H De Novo Reconstruction of Functional Bone by Tissue Engineering in the Metatarsal Sheep Model. Tissue Engineering 2005;11:814-824.

6 Bigi A, Cojazzi G, Panzavolta S, Ripamonti A, Roveri N, Romanello M, Suarez KN, Moro L Chemical and Structural Characterization of the Mineral Phase from Cortical and Trabecular Bone. Journal of Inorganic Biochemistry 1997;68:45-51. 
Bohner M, Gbureck U, Barralet JE Technological Issues for the Development of More Efficient Calcium Phosphate Bone Cements: A Critical Assessment. Biomaterials 2005;26:6423-6429. Castro P, Huber ME Marine Biology. McGraw-Hill Higher Education, Boston 2008.

9 Chen F, Feng X, Wu W, Ouyang H, Gao Z, Cheng X, Hou R, Mao T Segmental Bone Tissue Engineering by Seeding Osteoblast Precursor Cells into Titanium Mesh-Coral Composite Scaffolds. International Journal Of Oral And Maxillofacial Surgery 2007;36:822-827.

10 Chen PY, Lin AYM, Lin YS, Seki Y, Stokes AG, Peyras J, Olevsky EA, Meyers MA, McKittrick J Structure and Mechanical Properties of Selected Biological Materials. Journal Of The Mechanical Behavior Of Biomedical Materials 2008a;1:208-226.

11 Chen PY, Lin AYM, McKittrickJ, Meyers MA Structure and Mechanical Properties of Crab Exoskeletons. Acta Biomaterialia 2008b;4:587-596.

12 Cirutteau (1979)Process of Purification of Coral and Its Use., France.

13 Clarke S, Hoskins, NL, Jordan, GR, Marsh, DR Healing of a Critical Sized Defect Using a Novel Tcp Bone Graft Substitute Jax ${ }^{\mathrm{TM}}$ in Association with Autologous Osteogenic Cells and Growth Factors. Bone 2007;40:939-947.

14 Cook EA, Cook JJ Bone Graft Substitutes and Allografts for Reconstruction of the Foot and Ankle. Clinics in Podiatric Medicine and Surgery 2009;26:589-605.

15 Corriero G, Longo C, Mercurio M, Marzano CN, Lembo G, Spedicato MT Rearing Performance of Spongia Officinalis on Suspended Ropes Off the Southern Italian Coast (Central Mediterranean Sea). Aquaculture 2004;238:195-205.

16 Coughlin MJ, Grimes JS, Kennedy MP Coralline Hydroxyapatite Bone Graft Substitute in Hindfoot Surgery. Foot \& Ankle International 2006;27:19-22.

17 Cui L, Liu B, Liu G, Zhang W, Cen L, Sun J, Yin S, Liu W, Cao Y Repair of Cranial Bone Defects with Adipose Derived Stem Cells and Coral Scaffold in a Canine Model. Biomaterials 2007;28:5477-5486.

18 Cunningham E, Dunne N, Walker G, Maggs C, Wilcox R, Buchanan F Hydroxyapatite Bone Substitutes Developed Via Replication of Natural Marine Sponges. Journal Of Materials ScienceMaterials In Medicine 2010;21:2255-2261.

19 dePaula SM, Huila MFG, Araki K, Toma HE Confocal Raman and Electronic Microscopy Studies on the Topotactic Conversion of Calcium Carbonate from Pomacea Lineate Shells into Hydroxyapatite Bioceramic Materials in Phosphate Media. Micron 2010;41:983-989.

20 Doherty MJ, Schlag G, Schwarz N, Mollan RAB, Nolan PC, Wilson DJ Biocompatibility of Xenogeneic Bone, Commercially Available Coral, a Bioceramic and Tissue Sealant for Human Osteoblasts. Biomaterials 1994;15:601-608.

21 Ellies LG, Carter JM, Natiella JR, Featherstone JDB, Nelson DGA Quantitative-Analysis of Early Invivo Tissue-Response to Synthetic Apatite Implants. Journal of Biomedical Materials Research 1988;22:137-148. 

Report of Long-Term Results. Journal Of Oral And Maxillofacial Surgery 2005;63:1712-1723. Felicio-Fernandes G, Laranjeira MCM Calcium Phosphate Biomaterials from Marine Algae. Hydrothermal Synthesis and Characterisation. Quimica Nova 2000;23:441-446.

24 Galea G, Kopman D, Graham BJM Supply and Demand of Bone Allograft for Revision Hip Surgery in Scotland (Vol 80, Pg 595, 1998). Journal Of Bone And Joint Surgery-British Volume 1998;80B:1087-1087.

Geiger F, Lorenz H, Xu W, Szalay K, Lorenz H, Claes L, Augat P, Richter W Vegf Producing Bone Marrow Stromal Cells (Bmsc) Enhance Vascularization and Resorption of a Natural Coral Bone Substitute. Bone 2007;41:516-522.

26 Giraud-Guille MM, Belamie E, Mosser G Organic and Mineral Networks in Carapaces, Bones and Biomimetic Materials. Comptes Rendus Palevol 2004;3:503-513.

Gravel M, Vago R, Tabrizian M Use of Natural Coralline Biomaterials as Reinforcing and GasForming Agent for Developing Novel Hybrid Biomatrices: Microarchitectural and Mechanical Studies. Tissue Engineering 2006;12:589-600.

Green D, Howard D, Yang X, Kelly M, Oreffo ROC Natural Marine Sponge Fiber Skeleton: A Biomimetic Scaffold for Human Osteoprogenitor Cell Attachment, Growth, and Differentiation. Tissue Engineering 2003;9:1159-1166.

Green D, Walsh D, Mann S, Oreffo ROC The Potential of Biomimesis in Bone Tissue Engineering: Lessons from the Design and Synthesis of Invertebrate Skeletons. Bone 2002;30:810-815.

Green DW Tissue Bionics: Examples in Biomimetic Tissue Engineering. Biomedical Materials 2008;3.

Griesshaber E, Schmahl WW, Neuser R, Pettke T, Blum M, Mutterlose J, Brand U Crystallographic Texture and Microstructure of Terebratulide Brachiopod Shell Calcite: An Optimized Materials Design with Hierarchical Architecture. American Mineralogist 2007;92:722-734.

Guillemin G, Patat JL, Fournie J, Chetail M The Use of Coral as a Bone-Graft Substitute. Journal Of Biomedical Materials Research 1987;21:557-567.

Hall TJ A Reappraisal of the Effect of Extracellular Calcium on Osteoclastic Bone-Resorption.

Biochemical and Biophysical Research Communications 1994;202:456-462.

Harriott VJ Can Corals Be Harvested Sustainably? Ambio 2003;32:130-133.

Harris CT, Cooper LF Comparison of Bone Graft Matrices for Human Mesenchymal Stem CellDirected Osteogenesis. Journal Of Biomedical Materials Research Part A 2004;68A:747-755.

Heinemann S, Ehrlich H, Knieb C, Hanke T Biomimetically Inspired Hybrid Materials Based on Silicified Collagen. International Journal Of Materials Research 2007;98:603-608. 
Critical-Sized Cranial Defect Model. Journal Of Biomedical Materials Research Part A 2007;80A:85-93.

Hu J, Russell JJ, Ben-Nissan B, Vago R Production and Analysis of Hydroxyapatite from Australian Corals Via Hydrothermal Process. Journal Of Materials Science Letters 2001;20:85-87.

Im HH, Park JH, Kim KN, Kim KM, Choi SH, Kim CK, Lee YK Organic-Inorganic Hybrids of Hydroxyapatite with Chitosan. In: Bioceramics 17, pp 729-732 2005.

Ivankovic H, Ferrer GG, Tkalcec E, Orlic S, Ivankovic M Preparation of Highly Porous Hydroxyapatite from Cuttlefish Bone. Journal Of Materials Science-Materials In Medicine 2009;20:1039-1046.

41 Jinawath S, Polchai D, Yoshimura M Low-Temperature, Hydrothermal Transformation of Aragonite to Hydroxyapatite. Materials Science \& Engineering C-Biomimetic And Supramolecular Systems 2002;22:35-39.

Kannan S, Rocha JHG, Agathopoulos S, Ferreira JMF Fluorine-Substituted Hydroxyapatite Scaffolds Hydrothermally Grown from Aragonitic Cuttlefish Bones. Acta Biomaterialia 2007;3:243249.

43 Kasioptas A, Geisler T, Putnis CV, Perdikouri C, Putnis A Crystal Growth of Apatite by Replacement of an Aragonite Precursor. Journal Of Crystal Growth 2010;312:2431-2440.

Kasperk C, Ewers R, Simons B, Kasperk R A Bone Substitute Made of Algae. Deutsche Zahnarztliche Zeitschrift 1988;43:116-119.

Khoushab F, Yamabhai M Chitin Research Revisited. Marine Drugs 8:1988-2012.

Kim JJ, Kim HJ, Lee KS Evaluation of Biocompatibility of Pprous Hydroxyapatite Developed from Edible Cuttlefish Bone. In: Bioceramics, Vol 20, Pts 1 and 2, pp 155-158 2008.

Kujala S, Raatikainen T, Ryhanen J, Kaarela O, Jalovaara P Composite Implant of Native Bovine Bone Morphogenetic Protein (Bmp) and Biocoral in the Treatment of Scaphoid Nonunions- a Preliminary Study. Scandinavian Journal of Surgery 2002;91:186-190.

Lahaye M, Robic A Structure and Functional Properties of Ulvan, a Polysaccharide from Green Seaweeds. Biomacromolecules 2007;8:1765-1774.

Landi E, Celotti G, Logroscino G, Tampieri A Carbonated Hydroxyapatite as Bone Substitute. Journal of the European Ceramic Society 2003;23:2931-2937.

50 Laza AL, Jaber M, Miehe-Brendle J, Demais H, Le Deit H, Delmotte L, Vidal L Green Nanocomposites: Synthesis and Characterization. Journal Of Nanoscience And Nanotechnology 2007;7:3207-3213.

51 Lee SJ, Lee YC, Yoon YS Characteristics of Calcium Phosphate Powders Synthesized from Cuttlefish Bone and Phosphoric Acid. Journal Of Ceramic Processing Research 2007;8:427-430. 
Maeno S, Niki Y, Matsumoto H, Morioka H, Yatabe T, Funayama A, Toyama Y, Taguchi T, Tanaka J

The Effect of Calcium Ion Concentration on Osteoblast Viability, Proliferation and Differentiation in Monolayer and 3d Culture. Biomaterials 2005;26:4847-4855.

54 Marchegiani F, Cibej E, Vergni P, Tosi G, Fermani S, Falini G Hydroxyapatite Synthesis from Biogenic Calcite Single Crystals into Phosphate Solutions at Ambient Conditions. Journal Of Crystal Growth 2009;311:4219-4225.

Martina M, Subramanyam G, Weaver JC, Hutmacher DW, Morse DE, Valiyaveettil S Developing Macroporous Bicontinuous Materials as Scaffolds for Tissue Engineering. Biomaterials 2005;26:5609-5616.

56 Muller WEG, Wimmer W, Schatton W, Bohm M, Batel R, Filic Z Initiation of an Aquaculture of Sponges for the Sustainable Production of Bioactive Metabolites in Open Systems: Example, Geodia Cydonium. Marine Biotechnology 1999;1:569-579.

Murugan R, Ramakrishna S Coupling of Therapeutic Molecules onto Surface Modified Coralline Hydroxyapatite. Biomaterials 2004;25:3073-3080.

Mygind T, Stiehler M, Baatrup A, Li H, Zoua X, Flyvbjerg A, Kassem M, Bunger C Mesenchymal Stem Cell Ingrowth and Differentiation on Coralline Hydroxyapatite Scaffolds. Biomaterials 2007;28:1036-1047.

59 Ohgushi H Coral Derived Porous Framework Having Different Chemical Compositions as a Scaffold for Osteoblastic Differentiation. In: Porous Materials for Tissue Engineering, pp 209-220 1997.

60 Okumus Z, Yildirim OS The Cuttlefish Backbone: A New Bone Xenograft Material? Turkish Journal Of Veterinary \& Animal Sciences 2005;29:1177-1184.

61 Oliveira JA, Grech JMR, Leonor IB, Mano JF, Reis RL Calcium-Phosphate Derived from Mineralized Algae for Bone Tissue Engineering Applications. Materials Letters 2007;61:3495-3499. Petite H, Viateau V, Bensaid W, Meunier A, de Pollak C, Bourguignon M, Oudina K, Sedel L, Guillemin G Tissue-Engineered Bone Regeneration. Nature Biotechnology 2000;18:959-963. Raabe D, Sachs C, Romano P The Crustacean Exoskeleton as an Example of a Structurally and Mechanically Graded Biological Nanocomposite Material. Acta Materialia 2005;53:4281-4292.

Rezwan K, Chen QZ, Blaker JJ, Boccaccini AR Biodegradable and Bioactive Porous Polymer/Inorganic Composite Scaffolds for Bone Tissue Engineering. Biomaterials 2006;27:34133431.

65 Ritter SK (1997)Boning Up. At the Human Body Shop, Bioceramics or Biopolymers Combined with Bone Cells and Growth Factor Are Likely to Lead the Parts List. Chem. Eng. News (1997). In: Chemical \& Engineering News. of Hydroxyapatite Scaffolds from Aragonitic Cuttlefish Bones. Journal Of Biomedical Materials Research Part A 2006;77A:160-168. 
Rocha JHG, Lemos AF, Agathopoulos S, Valerio P, Kannan S, Oktar FN, Ferreira JMF Scaffolds for Bone Restoration from Cuttlefish. Bone 2005a;37:850-857.

68 Rocha JHG, Lemos AF, Kannan S, Agathopoulos S, Ferreira JMF Hydroxyapatite Scaffolds Hydrothermally Grown from Aragonitic Cuttlefish Bones. Journal Of Materials Chemistry 2005b;15:5007-5011.

Roy DM, Linnehan SK Hydroxyapatite Formed from Coral Skeletal Carbonate by Hydrothermal Exchange. Nature 1974;247:220-222.

Schopper C, Ziya-Ghazvini F, Goriwoda W, Moser D, Wanschitz F, Spassova E, Lagogiannis G, Auterith A, Ewers R Ha/Tcp Compounding of a Porous Cap Biomaterial Improves Bone Formation and Scaffold Degradation - a Long-Term Histological Study. Journal Of Biomedical Materials Research Part B-Applied Biomaterials 2005;74B:458-467.

71 Shors EC Coralline Bone Graft Substitutes. Orthopedic Clinics Of North America 1999;30:599-+. Sivakumar M, Kumar TSS, Shantha KL, Rao KP Development of Hydroxyapatite Derived from Indian Coral. Biomaterials 1996;17:1709-1714.

Spassova E, Gintenreiter S, Halwax E, Moser D, Schoppeir C, Ewers R Chemistry, Ultrastructure and Porosity of Monophasic and Biphasic Bone Forming Materials Derived from Marine Algae. Materialwissenschaft Und Werkstofftechnik 2007;38:1027-1034.

Summers BN, Eisenstein SM Donor Site Pain from the Ilium - a Complication of Lumbar Spine Fusion. Journal of Bone and Joint Surgery-British Volume 1989;71-B:677-680.

Tuominen T, Jamsa T, Tuukkanen J, Nieminen P, Lindholm TC, Lindholm TS, Jalovaara P Native Bovine Bone Morphogenetic Protein Improves the Potential of Biocoral to Heal Segmental Canine Ulnar Defects. International Orthopaedics 2000;24:289-294.

Turhani D, Cvikl B, Watzinger E, Weissenbock M, Yerit K, Thurnher D, Lauer G, Ewers R In Vitro Growth and Differentiation of Osteoblast-Like Cells on Hydroxyapatite Ceramic Granule Calcified from Red Algae. Journal Of Oral And Maxillofacial Surgery 2005a;63:793-799.

Turhani D, Watzinger E, Weissenbock M, Cvikl B, Thurnber D, Wittwer G, Yerit K, Ewers $R$ Analysis of Cell-Seeded 3-Dimensional Bone Constructs Manufactured in Vitro with Hydroxyapatite Granules Obtained from Red Algae. Journal Of Oral And Maxillofacial Surgery 2005b;63:673-681. Turhani D, Weissenbock M, Watzinger E, Yerit K, Cvikl B, Ewers R, Thurnher D In Vitro Study of Adherent Mandibular Osteoblast-Like Cells on Carrier Materials. International Journal Of Oral And Maxillofacial Surgery 2005c;34:543-550.

79 Vecchio KS, Zhang X, Massie JB, Wang M, Kim CW Conversion of Bulk Seashells to Biocompatible Hydroxyapatite for Bone Implants. Acta Biomaterialia 2007a;3:910-918.

80 Vecchio KS, Zhang X, Massie JB, Wang M, Kim CW Conversion of Sea Urchin Spines to MgSubstituted Tricalcium Phosphate for Bone Implants. Acta Biomaterialia 2007b;3:785-793. 
Viateau V, Guillemin G, Bousson V, Oudina K, Hannouche D, Sedel L, Logeart-Avramoglou D, Petite H Long-Bone Critical-Size Defects Treated with Tissue-Engineered Grafts: A Study on Sheep. Journal Of Orthopaedic Research 2007;25:741-749. von Doernberg MC, von Rechenberg B, Bohner M, Grunenfelder S, van Lenthe GH, Muller R, Gasser B, Mathys R, Baroud G, Auer J In Vivo Behavior of Calcium Phosphate Scaffolds with Four Different Pore Sizes. Biomaterials 2006;27:5186-5198.

83 Walsh PJ, Buchanan FJ, Dring M, Maggs C, Bell S, Walker GM Low-Pressure Synthesis and Characterisation of Hydroxyapatite Derived from Mineralise Red Algae. Chemical Engineering Journal 2008;137:173-179.

84 White E, Shors EC Biomaterial Aspects of Interpore-200 Porous Hydroxyapatite. Dental Clinics Of North America 1986;30:49-67.

85 White E, Shors EC (1989)Coated Biomaterials and Methods for Making Same., US.

86 White EW Biomaterials Innovation: It's a Long Road to the Operating Room. Materials Research Innovations 1997; 1:57-63.

87 White RA, White EW, Weber JN Replamineform - New Process for Preparing Porous Ceramic, Metal, and Polymer Prosthetic Materials. Science 1972;176:922-\&.

88 Wiesmann HP, Joos U, Meyer U Biological and Biophysical Principles in Extracorporal Bone Tissue Engineering Part Ii. International Journal Of Oral And Maxillofacial Surgery 2004;33:523530.

89 Wooley P, Nasser S, Fitzgerald R The Immune Response to Implant Materials in Humans. Clinical Orthopaedics and Related Research 1996;326:63-70.

90 Yamada S, Heymann D, Bouler JM, Daculsi G Osteoclastic Resorption of Calcium Phosphate Ceramics with Different Hydroxyapatite Beta-Tricalcium Phosphate Ratios. Biomaterials 1997;18:1037-1041.

91 Zaidi M, Datta HK, Patchell A, Moonga B, Macintyre I Calcium-Activated Intracellular Calcium Elevation - a Novel Mechanism of Osteoclast Regulation. Biochemical and Biophysical Research Communications 1989;163:1461-1465.

92 Zhang F, Chang J, Lu J, Lin K, Ning C Bioinspired Structure of Bioceramics for Bone Regeneration in Load-Bearing Sites. Acta Biomaterialia 2007a;3:896-904.

93 Zhang YF, Wang YN, Shi B, Cheng XR A Platelet-Derived Growth Factor Releasing Chitosan/Coral Composite Scaffold for Periodontal Tissue Engineering. Biomaterials 2007b;28:1515-1522.

94 Zheng MH, Hinterketiser K, Solomon K, Kunert V, Pavlos NJ, Xu J Collagen-Derived Biomaterials in Bone and Cartilage Repair. Macromolecular Symposia 2007;253:179-185. 


\section{Figure Legends}

Figure 1. Scanning electron micrographs of (a) cuttlefish (Sepia officinalis), (b) sponge (Spongia agaricina), (c) red algae (Corallina officinalis) and (d) coccolithophores (Emiliania huxleyi)demonstrating a range of macro and microporous structures. E.huxleyi micrograph courtesy of Katherine Fee.

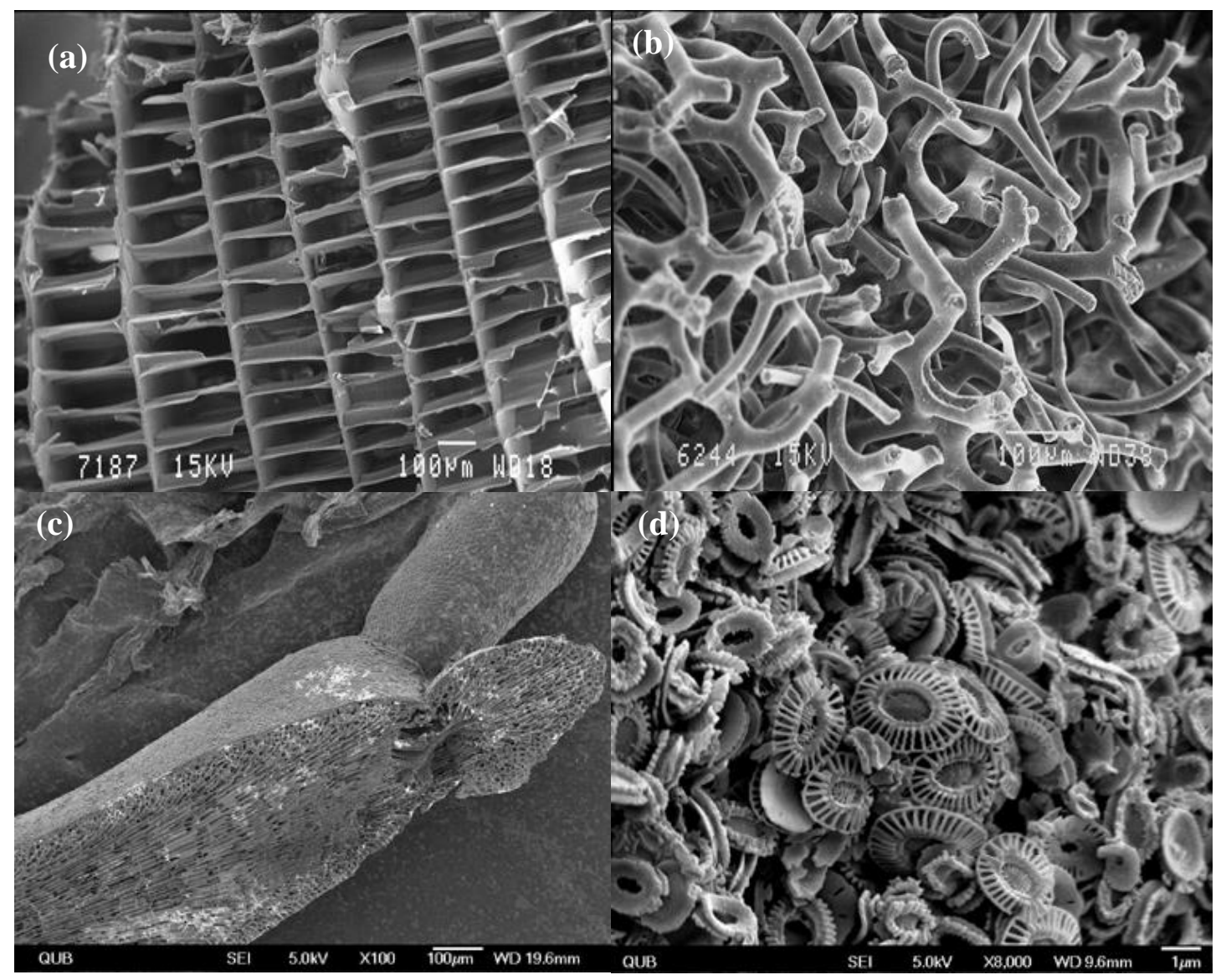


Table 1. Commercially available bone graft products from marine sources.

\begin{tabular}{|c|c|c|c|c|}
\hline Product & Manufacturer & $\begin{array}{l}\text { Country of } \\
\text { Origin }\end{array}$ & Genera & Chemistry \\
\hline Biocoral & Inoteb & France & $\begin{array}{l}\text { Porites, } \\
\text { Acropora, } \\
\text { Lobophyllia, } \\
\text { Montastrea, } \\
\text { Dichocoenia }\end{array}$ & $\mathrm{CaCO}_{3}$ \\
\hline $\begin{array}{l}\text { ProOsteon } \\
200 R\end{array}$ & Biomet & US & Porites & $\mathrm{HA} / \mathrm{CaCO}_{3}$ \\
\hline $\begin{array}{l}\text { ProOsteon } \\
500 R\end{array}$ & Biomet & US & Goniopora & $\mathrm{HA} / \mathrm{CaCO}_{3}$ \\
\hline Algipore & $\begin{array}{l}\text { DENTSPLY } \\
\text { Friadent }\end{array}$ & Germany & $\begin{array}{l}\text { Corallina } \\
\text { officinalis }\end{array}$ & $\mathrm{HA}$ \\
\hline
\end{tabular}


Table 2. Examples of manufacture processes used to fabricate marine-derived/inspired bone grafts. Key: CS

$=$ Closed System, autoclave OP = Open System, reaction vessel HPT - High Pressure-TemperatureHT - High Temperature $\beta$ TCP =

Tri-calcium phosphate $\beta \mathrm{TCMP}=$ Mg-substituted tri-calcium phosphate

\begin{tabular}{|c|c|c|c|c|c|c|}
\hline $\begin{array}{l}\text { Common } \\
\text { Name }\end{array}$ & Genera/Species & Source & Fabrication Technique & Chemistry & Yr & Ref \\
\hline Clams & Tridacna gigas & Unspecified & $\begin{array}{l}\text { HT Synthesis with superheated } \\
\text { steam (CS) }-180^{\circ} \mathrm{C}(20 \text { days) }\end{array}$ & $\begin{array}{l}\text { Complete transformation } \\
\text { to } \mathrm{HA}\end{array}$ & 2007 & $\begin{array}{l}\text { (Vecc } \\
\text { hio et } \\
\text { al., } \\
2007 \\
\text { a) }\end{array}$ \\
\hline \multirow{6}{*}{ Corals } & Goniopora & $\begin{array}{l}\text { Gulf of } \\
\text { Mannar, } \\
\text { India }\end{array}$ & $\begin{array}{l}\text { Microwave irradiation - } 800 \mathrm{~W} \\
\text { for } 40 \text { mins at } 2.45 \mathrm{GHz}\end{array}$ & $\begin{array}{l}\text { Complete transformation } \\
\text { to biphasic CaP with HA: } \\
\beta \text { TCP Phases }\end{array}$ & 2003 & $\begin{array}{l}\text { (Mur } \\
\text { ugan } \\
\text { and } \\
\text { Rama } \\
\text { krish } \\
\text { na, } \\
\text { 2004) }\end{array}$ \\
\hline & Porites & Unspecified & $\begin{array}{l}\text { HT Synthesis with vapour } \\
\text { pressure (CS) }-160-200^{\circ} \mathrm{C} \text { at } 1- \\
2 \mathrm{MPa}(8-14 \mathrm{hrs})\end{array}$ & $\begin{array}{l}\text { Complete transformation } \\
\text { to } \mathrm{HA}\end{array}$ & 2002 & $\begin{array}{l}\text { (Jina } \\
\text { wath } \\
\text { et al., } \\
\text { 2002) }\end{array}$ \\
\hline & Goniopora & $\begin{array}{l}\text { Great } \\
\text { barrier } \\
\text { Reef, } \\
\text { Australian }\end{array}$ & $\begin{array}{l}\text { (1) Acid digest ( } 5 \% \mathrm{NaClO}) ;(2) \\
\text { HPT Synthesis (CS) }-250^{\circ} \mathrm{C} \text { at } \\
2.8 \mathrm{MPa}\end{array}$ & $\begin{array}{l}\text { Complete transformation } \\
\text { to a monophasic HA }\end{array}$ & 2001 & $\begin{array}{l}\text { (Hu } \\
\text { et al., } \\
2001)\end{array}$ \\
\hline & Goniopora & $\begin{array}{l}\text { Gulf of } \\
\text { Mannar, } \\
\text { India }\end{array}$ & $\begin{array}{l}\text { (1) Pyrolysis } 900^{\circ} \mathrm{C}(12 \mathrm{hrs}) \\
\text { (2) HPT Synthesis }\end{array}$ & $\begin{array}{l}\text { HA - Process destroyed } \\
\text { structure }\end{array}$ & 1996 & $\begin{array}{l}\text { (Sivak } \\
\text { umar } \\
\text { et al., } \\
\text { 1996) }\end{array}$ \\
\hline & Goniopora; Porites & Unspecified & $\begin{array}{l}\text { HPT Synthesis (CS) }-270^{\circ} \mathrm{C} \text { at } \\
103 \mathrm{MPa}\end{array}$ & $\begin{array}{l}\text { Complete transformation } \\
\text { of coral to a monophasic } \\
\mathrm{CaP}\end{array}$ & 1974 & $\begin{array}{l}\text { (Roy } \\
\text { and } \\
\text { Linne } \\
\text { han, } \\
\text { 1974) }\end{array}$ \\
\hline & Goniopora; Porites & Unspecified & Replication using wax casting & $\begin{array}{l}\mathrm{TiO}_{2}, \mathrm{Al}_{2} \mathrm{O}_{3} \text { and } \mathrm{HA} \\
\text { synthetic replicas of coral } \\
\text { structures }\end{array}$ & 1972 & $\begin{array}{l}\text { (Whit } \\
\text { e et } \\
\text { al., } \\
\text { 1972) }\end{array}$ \\
\hline \multirow{3}{*}{ Cuttlefish } & Sepia officinalis & $\begin{array}{l}\text { New South } \\
\text { Wales, } \\
\text { Australia }\end{array}$ & $\begin{array}{l}\text { Hydrothermal Synthesis with } \\
\text { superheated steam (CS) }-80^{\circ} \mathrm{C} \\
(32 \mathrm{hrs})-190^{\circ} \mathrm{C}(1.5 \mathrm{hrs})\end{array}$ & $\begin{array}{l}\text { Complete transformation } \\
\text { to a monophasic HA }\end{array}$ & 2010 & $\begin{array}{l}\text { (Kasio } \\
\text { ptas } \\
\text { et al., } \\
\text { 2010) }\end{array}$ \\
\hline & Sepia officinalis & Adriatic Sea & $\begin{array}{l}\left.\text { (1) Pyrolysis } 350^{\circ} \mathrm{C} \text { ( } 3 \mathrm{hrs}\right) \\
\text { (2) HT Synthesis, superheated } \\
\text { steam (CS) }-200^{\circ} \mathrm{C} \text { ( } 48 \mathrm{hrs} \text { ) }\end{array}$ & $\begin{array}{l}\text { Complete transformation } \\
\text { to monophasic HA }\end{array}$ & 2009 & $\begin{array}{l}\text { (Ivan } \\
\text { kovic } \\
\text { et al., } \\
\text { 2009) }\end{array}$ \\
\hline & Sepia esculenta & Unspecified & $\begin{array}{l}\text { (1) Acid digest ( } 4 \% \mathrm{NaClO}) \text {; } \\
\text { (2) Pyrolysis } 180^{\circ} \mathrm{C}(16 \mathrm{hrs})\end{array}$ & Predominantly $\mathrm{HA}$ & 2008 & $\begin{array}{l}\text { (Kim } \\
\text { et al., }\end{array}$ \\
\hline
\end{tabular}




\begin{tabular}{|c|c|c|c|c|c|c|}
\hline & & & $\begin{array}{l}\text { HT Synthesis superheated steam } \\
\text { (CS) }-200^{\circ} \mathrm{C}(24 \mathrm{hrs})\end{array}$ & & & 2008) \\
\hline \multirow[b]{2}{*}{ Red algae } & Corallina officinalis & $\begin{array}{l}\text { Donegal, } \\
\text { Ireland }\end{array}$ & $\begin{array}{l}\text { (1) Pyrolysis } 650^{\circ} \mathrm{C}(12 \mathrm{hrs}) \\
\text { (2) LP Hydrothermal Synthesis - } \\
\text { (OS) }-100^{\circ} \mathrm{C} \text { (24hrs) }\end{array}$ & $\begin{array}{l}\text { Complete transformation } \\
\text { to a biphasic CaP with } \approx \\
95 \% \text { HA: } \beta \text { TCP Phases }\end{array}$ & 2008 & $\begin{array}{l}\text { (Wals } \\
\text { h et } \\
\text { al., } \\
\text { 2008) }\end{array}$ \\
\hline & $\begin{array}{l}\text { Rhodophyta } \\
\text { (species } \\
\text { unspecified) }\end{array}$ & $\begin{array}{l}\text { Santa } \\
\text { Catarina } \\
\text { Island }\end{array}$ & $\begin{array}{l}\text { (1) Acid digest (10\% } \mathrm{NaClO}) \text {; (2) } \\
\text { HT Hydrothermal Synthesis (CS) } \\
\text { superheated steam }-200^{\circ} \mathrm{C} \\
\text { (48hrs) }\end{array}$ & $\begin{array}{l}\text { Complete transformation } \\
\text { to a monophasic } \mathrm{HA} \text { with } \\
\text { trace } \mathrm{Mg}^{2+} \mathrm{Na}^{+} \text {ions }\end{array}$ & 2000 & $\begin{array}{l}\text { (Felici } \\
\text { o- } \\
\text { Ferna } \\
\text { ndes } \\
\text { and } \\
\text { Laran } \\
\text { jeira, } \\
\text { 2000) }\end{array}$ \\
\hline \multirow{3}{*}{ Sea urchins } & $\begin{array}{l}\text { Paracentrotus } \\
\text { lividus; } \\
\text { Heterocentrotus } \\
\text { mammillatus }\end{array}$ & Unspecified & Precipitation- $20^{\circ} \mathrm{C}$ (2 Mths) & HA & 2009 & $\begin{array}{l}\text { (Marc } \\
\text { hegia } \\
\text { ni et } \\
\text { al., } \\
\text { 2009) }\end{array}$ \\
\hline & $\begin{array}{l}\text { Heterocentrotus } \\
\text { mammillatus } \\
\text { Heterocentrotus } \\
\text { trigonarius }\end{array}$ & Unspecified & $\begin{array}{l}\text { HT Hydrothermal Synthesis with } \\
\text { superheated steam (CS) }-180^{\circ} \mathrm{C}\end{array}$ & $\begin{array}{l}\text { Complete transformation } \\
\text { of spines to } \beta T C M P\end{array}$ & 2007 & $\begin{array}{l}\text { (Vecc } \\
\text { hio et } \\
\text { al., } \\
2007 \\
\text { b) }\end{array}$ \\
\hline & Unspecified & Unspecified & $\begin{array}{l}\text { Replication using polymer } \\
\text { casting }\end{array}$ & $\mathrm{CaCO}_{3}$ & 2006 & $\begin{array}{l}\text { (Guill } \\
\text { emin } \\
\text { et al., } \\
\text { 1987) }\end{array}$ \\
\hline Snails & Pomacea lineata & Unspecified & $\begin{array}{l}\text { Precipitation- Room } \\
\text { Temperature }-7,14,30 \text { days }\end{array}$ & Aragonite with $\mathrm{HA}$ coating & 2010 & $\begin{array}{l}\text { (dePa } \\
\text { ula et } \\
\text { al., } \\
\text { 2010) }\end{array}$ \\
\hline Sponges & Spongia agaricina & Caribbean & $\begin{array}{l}\text { Replication using HA slurry and } \\
\text { sintering at } 1300^{\circ} \mathrm{C} \text { (5hrs) }\end{array}$ & HA & 2010 & $\begin{array}{l}\text { (Cunn } \\
\text { ingha } \\
\mathrm{m} \text { et } \\
\text { al., } \\
2010 \text { ) }\end{array}$ \\
\hline
\end{tabular}


Table 3. Examples of mineralizing marine organisms. Those that have already been investigated for bone tissue engineering are highlighted in bold.

\begin{tabular}{llll} 
Phylum & Class & Common Name & Skeletal Mineral \\
Heterokontophyta & Bacillariophyta & Diatoms & Silica \\
\hline Haptophyta & Prymnesiophyceae & Coccolithophorids & $\mathrm{CaCO}_{3}$ \\
\hline Radiolaria & Polycystina & Radiolarians & silica \\
\hline Foraminifera & Granuloreticulosa & Foraminiferans & $\mathrm{CaCO}_{3}$ \\
\hline Rhodophyta & Florideophyceae & Red algae & $\mathrm{CaCO}_{3} /$ calcite \\
\hline Ectoprocta & Stenolaemata & Bryozoans & $\mathrm{CaCO}_{3}$ \\
\hline Porifera & Demospongia & Sponges & $\mathrm{CaCO}_{3}$ and/or silica \\
\hline Cnidarians & Anthozoa & Corals & $\mathrm{CaCO}_{3} /$ aragonite \\
\hline Mollusca & Gastropoda & Snails, limpets & $\mathrm{CaCO}_{3} /$ aragonite \\
& Bivalvia & Clams, mussels & $\mathrm{CaCO}_{3} /$ aragonite \\
& Cephalopods & Squid, cuttlefish & $\mathrm{CaCO}_{3} /$ aragonite \\
\hline Brachiopoda & Crustacea & Lobster, crab, shrimp & $\mathrm{CaCO}_{3} /$ aragonite \\
\hline Echinodermata & Asteroidea & Starfish & $\mathrm{CaCO}_{3}$ or CaPO \\
\hline Erthropoda & Ophinoidea & Sea urchins & $\mathrm{CaCO}_{3} /$ calcite \\
\hline $\mathrm{CaCO}_{3} /$ calcite \\
\hline $\mathrm{CaCO}_{3} /$ calcite \\
\hline
\end{tabular}

